\title{
Audiovisual Cartography: Established and New Multimedia Approaches to Represent Soundscapes
}

\author{
Dennis Edler ${ }^{1}$ · Olaf Kühne ${ }^{2} \cdot$ Julian Keil ${ }^{1}$. Frank Dickmann ${ }^{1}$
}

Received: 12 December 2018 / Accepted: 7 January 2019 / Published online: 4 February 2019

(c) The Author(s) 2019

\begin{abstract}
Since the mid-1990s, sound has been discussed and used in multimedia cartography. There are four main variants of auditory map elements that have been established in the theory and practice of audiovisual cartography, i.e. abstract sounds/abstract sound sequences, speech, music and, especially, audiorealistic sequences representing so-called "soundscapes". In cartography, soundscapes are often addressed in large-scale representations. The term originates in multidisciplinary landscape research. Empirical findings of landscape research, and especially those of social constructivist landscape research, have shown the relevance of non-visual stimuli for people's individual impressions and meanings of the experienced landscape. Amongst the non-visual landscape dimensions, the auditory dimension is the most prominent one. As 3D cartography offers new methods and techniques of designing and experiencing highly realistic, incl. photo- and audiorealistic landscape representation, this discipline becomes more and more interesting for simulating and presenting multisensory landscapes and for presenting the results of empirical findings in landscape research. After an introduction to traditional means of audiovisual cartography and the relevance of auditory stimuli for social constructivist approaches of landscape research, a modern software-based method is presented which highlights the opportunity to imbed 3D sound data representing a location's soundscape into audiovisual 3D environments in Virtual Reality (VR). It is technically based on the cross-platform game engine Unity3D.
\end{abstract}

Keywords Audiovisual cartography $\cdot$ Multimedia cartography $\cdot$ Multisensory cartography $\cdot$ Landscapes $\cdot$ Soundscapes . Virtual reality $(\mathrm{VR}) \cdot$ Unity 3D

\section{Zusammenfassung}

Audiovisuelle Kartographie: Etablierte und neue Methoden zur Repräsentation von Klanglandschaften

Seit Mitte der 1990er Jahren wird die akustische Dimension in der Multimediakartographie diskutiert und eingesetzt. Seither haben sich hauptsächlich vier Ausprägungen durchgesetzt, die als akustische Kartenelemente verwendet werden: abstrakte Töne und Tonfolgen, Sprache, Musik und audiorealistische Sequenzen zur Darstellung so genannter soundscapes (dt. „Klanglandschaften“). In der Kartographie beziehen sich Darstellungen von Klanglandschaften häufig auf großmaßstäbige Raumausschnitte. Der Begriff entstammt der multidisziplinären Landschaftsforschung. Empirische Erkenntnisse der Landschaftsforschung, insbesondere der sozialkonstruktivistischen Landschaftsforschung verdeutlichen, dass nicht-visuelle Reize der Landschaft die individuelle Interpretation der erfahrenen Landschaft maßgeblich beeinflussen. Unter den nichtvisuellen Landschaftsdimensionen gilt die akustische Dimension als bedeutendste. Aktuelle Entwicklungen zu Methoden und Techniken der 3D-Kartographie bieten Möglichkeiten zur hochrealistischen Gestaltung und Erfahrung audio-visueller 3D-Landschaften. Dies kann die Landschaftsforschung durch moderne multisensorische Darstellungsformen sowie Ergebnispräsentationen unterstützen. Dieses Paper führt ein in traditionelle Darstellungsvarianten der audiovisuellen Kartographie und diskutiert die Bedeutung der Klanglandschaften für die (sozialkonstruktivistische) Landschaftsforschung. Im Anschluss wird ein aktuelle Software-gestützte Methode zur Implementierung von audiorealistischem 3D-Sound in 3D-Landschaften in Virtual Reality (VR) vorgestellt. Dies basiert auf der plattformübergreifenden Spiele-Engine Unity3D.

Extended author information available on the last page of the article 
Schlüsselwörter Audiovisuelle Kartographie $\cdot$ Multimediakartographie $\cdot$ Multisensorische Kartographie $\cdot$ Landschaft · Klanglandschaft · Virtual Reality (VR) · Unity 3D

\section{Introduction}

The origins of using sound in maps are often associated with John B. Krygier. His pioneering research article entitled "Sound and Geographic Visualization" (Krygier 1994)— inspired by his own seminar paper in Psychology (Krygier 1991)—fundamentally changed a traditional point of view on making maps and cartographic communication. His set of "abstract sound variables"-influenced by Jacques Bertin's (1967) six graphical variables—gave a 'multisensory impulse' to theoretical and practical cartography. The typology of Krygier's nine abstract sound variables suggests that spatially represented information can be differentiated by specific attributes of sound, i.e. location (the position of a sound), loudness (the magnitude of a sound), pitch (the highness or lowness of a sound), register (the relative location of a pitch in a given range of pitches), timbre (the general prevailing quality or characteristic of a sound), duration (the length of time a sound is or is not heard), rate of change (the varying duration of a sound over time), order (the sequence of sound over time) and attack/decay (the time it takes a sound to reach its maximum/minimum). Perceivable changes/differences of these sound variables likely-a clear empirical verification is still missing by today (Ballatore et al. 2018; Lammert-Siepmann et al. 2017; Schiewe 2015)—facilitate a proper decoding of auditorily encoded spatial information.

Krygier's idea of cartographically representing ordinal and nominal (geographical) data using sound features, i.e. spatio-temporal auditory map animations, was published at a time where cartography and neighbouring disciplines rapidly shifted from analogue to digital solutions (MacEachren 2004; Müller et al. 2001; Müller and Laurini 1997). The formation of information societies, going along with the computerization of the job market and private households, had caused the fast and competitive development of digital (multi-)media products as well as mass-market software. Animation (flagship) software, such as "Future Splash Animator" or "Macromedia Flash", allowed the 'programming' of maps, instead of only drawing them as usual (Scharlach 2002).

The paradigm shift from analogue to digital cartography required new methodological fundamentals in cartography (see also Brauen 2006; Buziek 1999; Müller 1997). To create an audiovisually animated map, cartographers had the new task to handle (such as record or find and download, cut and edit) sounds and to implement these sound elements into interactive map frameworks-by writing (usually objectoriented) programming/scripting code.
From the mid-1990s onwards, a large bouquet of audiovisual maps has been published in academic papers and launched online-many of these maps were obviously influenced by animated spatial visualizations released by other creative industries, such as animated cartoons (Garfield 2012; Harrower 2004; Peterson 1999) and video/computer games (Edler et al. 2018b; Edler and Dickmann 2016, 2017; Ahlqvist 2011). Nevertheless, compared to purely graphical maps (originating in traditional methods of map-making), the today existing number of audiovisual maps is still very limited (Dickmann 2018, p 170). Without the possibility of considering each of these audiovisual cartographic publications, a set of specific variants of cartographic sound elements has become apparent: (1) computer-generated abstract sounds (and sound sequences), (2) human or computer-simulated speech, (3) recorded or computer-generated music and (4) 'audiorealistic' recordings of the real 'soundscape' (or computer-simulated imitations).

The most 'geographical' of these sound variants in audiovisual cartography is the audiorealistic representation of the "soundscape", a term coined by Schafer (1977). The term represents the compilation of perceivable sounds in the physical landscape at a specific place over a specific period of time. The possibility of recording the soundscape allows a very close and detailed relation between the map and the multisensory landscape represented in the map (Edler et al. 2012; Laakso and Sarjakoski 2010). The represented soundscape may also document different experiences made by individuals and groups of society (see also Wissmann 2014). Thus, the soundscape and its technical representation based on audiovisual cartography can be closely related to social constructivist approaches of landscape research (Edler et al. 2018a).

This article is dedicated to the linkage between the meaning and relevance of soundscape for landscape research and modern interactive visualization techniques of audiovisual cartography (in 3D). Before going into these details, the established variants of sounds which have traditionally been used in audiovisual maps are introduced.

\section{Examples of Established Sound Variants in Audiovisual Cartography}

This chapter intends to give a short and compact overview of the four established variants of sound in audiovisual cartography. Some examples are contained in figures to offer, at least some, additional visual impressions. 


\subsection{Abstract Sounds}

The use of abstract sounds (simple tones) in cartography is a plain and pure way of implementing acoustic elements. On the one hand, it can be used to convey semantic information in the map, such as changes in noise emission/noise pollution (Schiewe and Weninger 2012; Kornfeld 2008; Scharlach 2002), positional accuracy of address locations (Bearman and Lovett 2010) or height information in topographic or physical map - the higher the terrain, the higher the tone (Schito 2011; see also Schito and Fabrikant 2018; Sobue et al. 2010). On the other hand, abstract sounds in audiovisual maps are also used to simply signalize that the content has just changed in an animated sequence. This signalizing function of abstract sounds was used by Krygier (1993, published online: 2012), who created a map showing variances in the nationwide distribution of Democratic or Republican college landslides in US elections. When the year changes in the map sequence, an abstract sound is played to indicate this change, going along with the display of a different electoral result. The years documented are additionally graphically represented by a time bar. Hence, the signalizing tone is a redundant feature in the audiovisual map (see Fig. 1).

\subsection{Speech}

Speech, either a recorded human or computer-generated voice, is a multifaceted and adaptable tool in multimedia cartography (see also Dickmann 2018; Lammert-Siepmann et al. 2014, 2017; Morrison and Ramirez 2001). It addresses the linguistic code of transferring facts or concepts. Users of mobile navigation systems know that spoken instructions help people to improve the effectiveness and efficiency of getting from A to B. Apart from 'acoustically enriched' satnavs, cartographers have used speech in different scenarios of educational applications: At the beginning, an (original or simulated) voice can give introductory comments of how to use an application, like a 'guiding agent' (Edler and Dodt 2010; Borchert 1999; Reagan and Baldwin 2006). These introductory (spoken) words can also help to contextualize the contents of the map application, such as providing background information about history and geography (Pulsifer et al. 2007; Francis 1999).

In the map itself, speech can be linked with specific geographical areas and give information about data and facts that can be read already (redundant information transfer), such as place names, land use categories or precipitation values. Recent cartographic research shows that the additional auditory communication of object names improves not only the memory of names (object-identities), but also the spatial accuracy of their corresponding object-locations (LammertSiepmann et al. 2017). The audiovisual communication of semantic attributes of represented spatial objects seems to improve the binding of object identity and object location, which even enhances the spatial accuracy of object-location memory.

Speech can also contain information which is additional to the graphically represented map contents. In the context
Fig. 1 Abstract sounds mark the change of the election year in the USA by Krygier (1993)

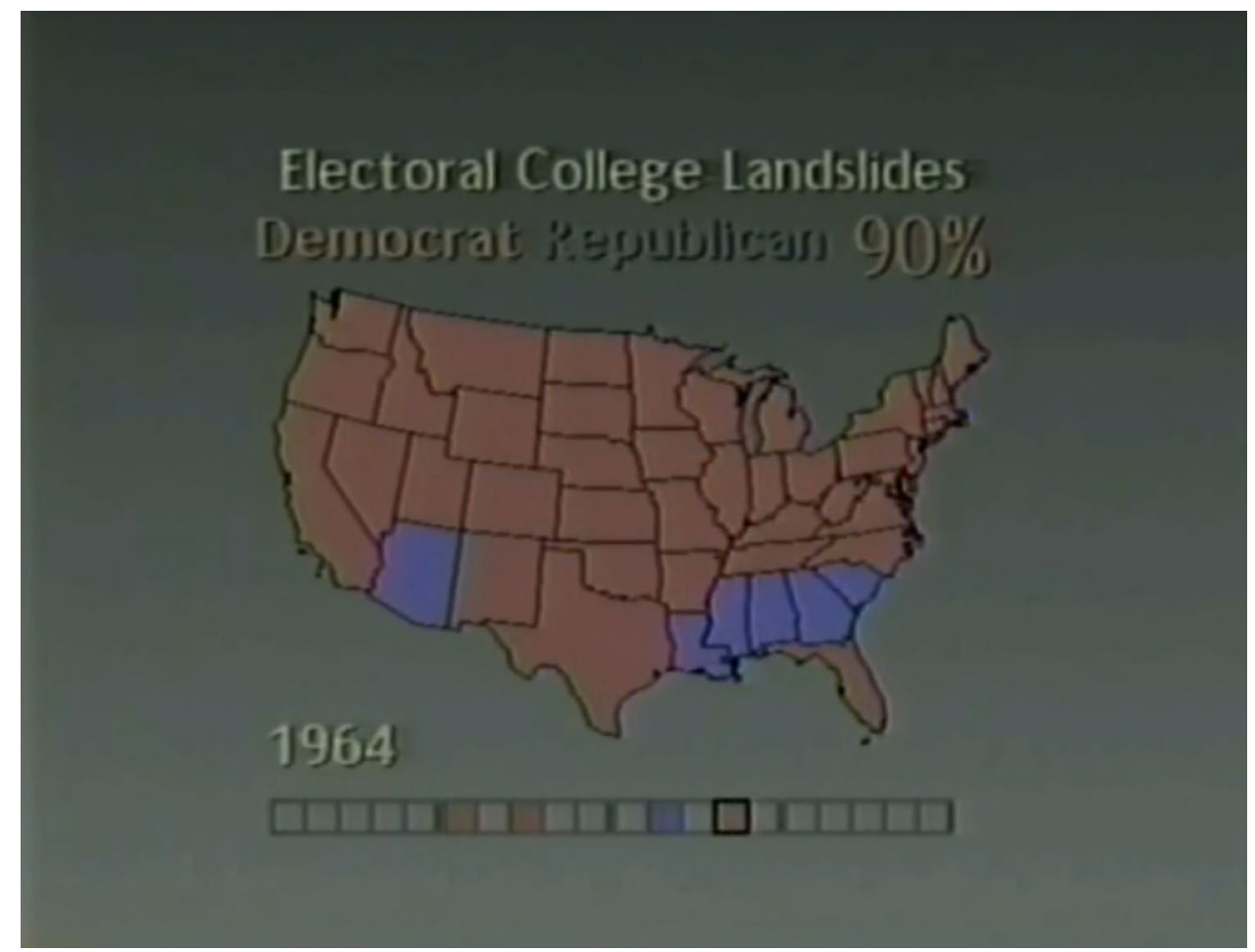


of learning a foreign language, speech can give, for instance, additional information about pronunciation, grammar and contextualized vocabulary (Edler et al. 2012; LammertSiepmann et al. 2011).

Speech can also provide additional information to an entirely different map theme (e.g. for young children), such as (learning) the approximate habitats of prominent worldwide animals and their usual habits and sounds (Edler and Lammert-Siepmann 2012). Figure 2 shows a young child operating with a modern audiovisual globe for children.

\subsection{Music}

Music is a highly complex and diversified sound and rhythm system with its own structural logic (Sonnenschein 2001). Generally, music in maps and map-like applications seems to encourage user pacing, it also transports emotional cues and it can have a motivating function (Brauen 2014; see also Buziek 1999). The sound variant music does not have an equivalent in the visual/graphical dimension of cartography (Edler et al. 2012), unlike abstract sounds (abstract symbols, usually explained in a map key) and speech (map lettering). However, music seems to fascinate some multimedia

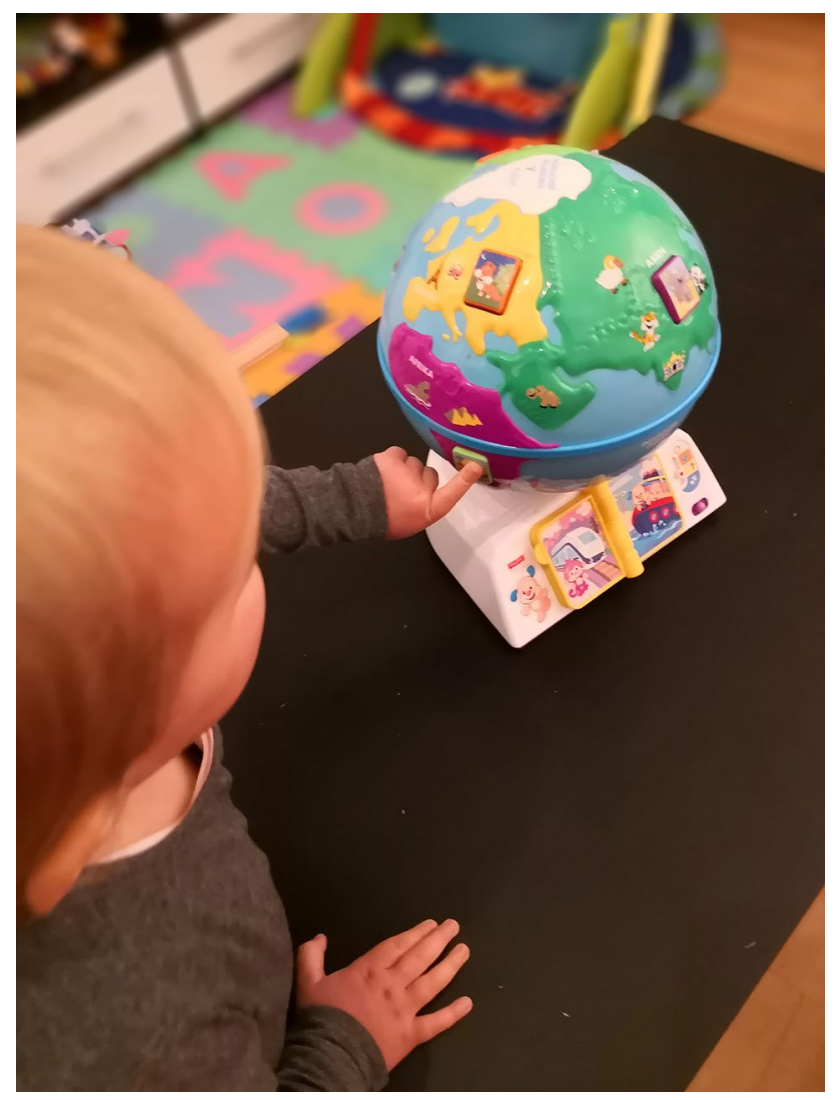

Fig. 2 A child is learning animals around the globe based on interaction and audiovisual presentation cartographers and so it is not surprising that musical elements have been used as cartographic elements in some audiovisual maps (Théberge 2005; see also Dickmann 2018, p 171).

Examples exist where music is used in the "intro" of a multimedia cartographic application. In the intro (an opening sequence before the main applications (maps) can be read and used), music usually creates a link between the theme and/or geographical location of the map(s), as known from the film industry, where music is often linked and associated with real or fictional locations (e.g. Star Wars, The Fresh Prince of Bel-Air or the 'Boom Chica Boom' song, by Johnny Cash, pointing to the 'Wild West' in the opening theme of Bonanza). In other words, music 'welcomes' the user/reader/spectator and "invokes a broader geographical context” (Pulsifer et al. 2007, p 208).

A multimedia cartographic example is an intro song sequence of Irish folk in an interactive and audiovisual map tutorial for studying Irish placenames (Edler and Dodt 2010). In an interactive atlas, dedicated to different nautical Antarctica explorations, classical music (String Quartet No. 3 by Wolfgang A. Mozart) introduces the Cook expedition (1772-75). Here, music (of the similar historical period) creates an aesthetic environment (Pulsifer et al. 2007; Siekierska and Armenakis 2007). Accompanying geographical locations and attributes by corresponding music is also a familiar strategy found in video games, where spatial stories are told based on interactive maps or map-like applications, such as Super Mario World or Sim City (Edler and Dickmann 2016, 2017; Grimshaw 2014; Théberge 2005).

In other multimedia cartographic applications, music is also used as a variable encoding and transporting geographical contents which cannot be received from the graphics. In a map on Canada's international trade relations (1976-2000), musical sequences and their different levels of loudness (see Krygier 1994) represent Canada's trade balance with different world regions (Brauen and Taylor 2008). Using the ambiguous map title "Rock Music", different particle sizes determined in sediment analyses of the Matanuska Glacier (Alaska) are represented by song sequences in another audiovisual map (Helmuth and Davis 2004). Compared to other sound variants, music is however rarely used in audiovisual cartography.

\subsection{Audiorealstic Recordings/Simulations of the 'Soundscape'}

By 'nature', audiorealistic recordings or computer-generated simulations of what can be acoustically experienced in the (physical) landscape ("soundscape", Schafer 1977) are closely linked. The signifier (sound element) and the signified (sound emitting object in the landscape) can have a high level of correspondence ('iconicity') in a map (Edler 
et al. 2012). An audiorealistic sound sequence can 'echo' an audible part of the whole concept it is supposed to represent ('pars pro toto'), comparable to graphic icons (such as pictograms) in mono-sensory (visual-only) maps. An example for this is a recorded sound sequence of a ringing bell (in graphics, for, e.g. a Christian cross) representing locations of Catholic or Protestant churches or monasteries. The other sound variants introduced above would either need a legend to establish a proper cartographic communication (abstract sounds) or could only handle a language-based component to put across the meaning (speech), or would-even in the case of using recordings of a well-known church song-suppose a much higher degree of (socio-)cultural background knowledge to decode and understand the signified object properly.

The example sketched above_ringing bell representing church, but Catholic or Protestant (?) —also indicates the degree of uncertainty carried over by 'pars pro toto audiorealistic sounds', which-in a bad case of cartographic communication - may also end up in "unpredictable sound/ image interactions" (Caquard et al. 2008). In the review of existing audiovisual maps containing audiorealistic sound elements, it becomes obvious that this variant of sound is more often used in large-scale maps (see also Aiello et al. 2016; Brauen 2014; Thirion 2007; Scharlach 2002) - to guarantee a high level of soundscape appropriateness and to avoid the problem of unpredictable uncertainty (Aiello et al. 2016; Axelsson 2015).

An example is a tourist map for visitors of the Finnish national park "Nuuksio", north-west from Helsinki. Before visiting the park, people are invited to experience recordings of peculiarities in the landscape cartographically, such as water falling from a dam in spring, or water (still) running in a frozen brook in cold winter times (Laakso and Sarjakoski 2010). Some other audiorealistic recordings are contained in an audiovisual tourist and educational map of the "Landschaftspark Duisburg-Nord" (Edler et al. 2015), a former industrial site in the Ruhr Area, Germany. Today's leisure activities in the park area, such as diving, climbing and a summer-time cinema, can be heard, by clicking on pictograms. (see more related examples in Brauen 2014 and Scharlach 2002). Figure 3 shows an interactive web-map of Tallinn, Estonia. The markers represent the locations of churches in and around the medieval core of the city. By clicking on the blue markers, the users can get an impression of the soundscapes in and around the church locations. The figure includes a video (audiovisual sequence) and includes a sound of the organ which can be listened to in the dome church of Tallinn ("St. Mary's Cathedral").

The public interest in 'mapping' audiorealistic sound sequences in the (physical) landscape becomes visible in such examples of large-scale audiovisual maps. It is also mirrored in social media and real-time cross-platform messengers (e.g. What's App), video-sharing websites (incl. sound streams, e.g. https://www.youtube.com/) and widely known (free) online sound databases (e.g. https:// freesound.org/). Individuals, but also groups with shared interests gather sound events they would like to keep, repeat and exchange. Apparently, audiorealistic sound seems to transport a special meaning to them and is considered as important (see also Papadimitriou et al. 2009).

The meaning and relevance of soundscapes are a research topic which is currently discussed in constructivist approaches of landscape research. Input of this multidisciplinary academic field bring in new discussions to cartography. In cartography, large-scale visualization methods are of rising importance, as these methods help to increase the currently demanded higher levels of realism in the final cartographic media (see Edler et al. 2018c; Hruby et al. 2018; Kersten et al. 2018; Coors et al. 2016; Günther-Diringer 2016; Dickmann and Dunker 2014).

\section{The Meaning and Relevance of Soundscapes}

Constructivist approaches of landscape research have established themselves in the last decades (e.g. Aschenbrand et al. 2017; Bruns and Kühne 2015; Gailing 2013; Greider and Garkovich 1994, Daniels and Cosgrove 1988; Cosgrove 1984, 1985; Kühne 2008a, 2009, 2018a). Especially the social constructivist landscape theory is suitable for the formation of 'multisensory' impressions. It is originating from phenomenological sociology (Schütz 1960, 1971 [1932]). In comparison to approaches of radical constructivism and discourse theory, where the focus is put on processes of social communication, social constructivist landscape research is rather dedicated to the material world (cf. Kühne 2018b; Weber 2018).

From a constructivist perspective, landscape is not understood as an 'objectively existing' object, which it is, in positivism, or as an 'entity' from the mutual imprinting of culture and nature, which it is, in essentialism (for more details on the approaches, see Kühne 2018c). From a social constructivist perspective, the constitutive level of landscape is formed by social patterns of interpretation and evaluation. These patterns are incorporated by individuals in the process of socialization. This enables individuals to synthesize the sensory impressions of material objects in their consciousness. It also allows them to communicate via the formed 'landscape', without the loss of social recognition (for more details, see Kühne 2018b, d; Wojtkiewicz and Heiland 2012). In the process of synthesizing the sensory impressions of material objects into landscape within the consciousness, not all sensory impressions are considered in the same way. A selection takes place that is based on social 


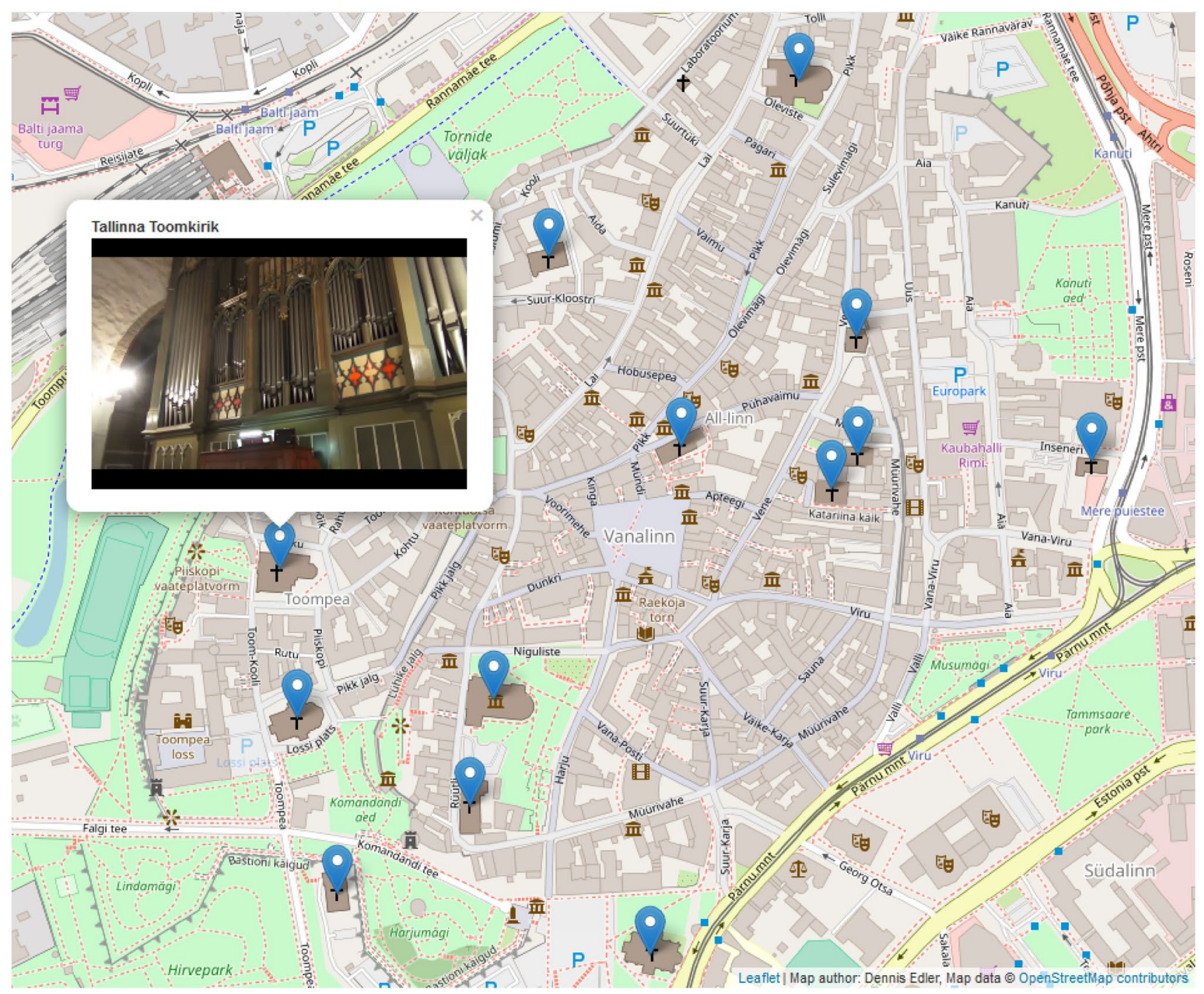

Fig. 3 Audiorealistic sounds and videos represent the perceivable soundscape in and around the churches of Tallinn's medieval old town in an interactive map (based on leaflet.js)

conventions, going along with a reduction of complexity (Weber et al. 2018, Burckhardt 2006).

The socialization of social patterns of landscape interpretation and evaluation is a diversified process (for more details, see Kühne 2008a, e; Stotten 2013): The formation of the 'native regular landscape' primarily happens during the direct confrontation with phenomena around the parental home, which are then interpreted as 'landscape' by formative others (especially parents and relatives). This landscape is formed in a normative way and regarded as 'normal'. The adolescent is then introduced to more general patterns of interpretation and evaluation of landscape. The mediation is more institutionally bound and influenced by school books, films, photos, paintings, and/or the Internet (see Kühne 2018e; Linke 2017). In this way, a 'stereotypical landscape' is shaped out. It represents a 'common sense' of an aesthetic, cognitive and functional nature, whereas the 'native regular landscape' has a more emotional quality. A third level of landscape socialization is formed by special knowledge of 'experts'. It is usually formed by academic study. Here, the patterns of interpretation and evaluation are strongly cognitively influenced. They differ a lot from each other, and they are in a distinctive competition with each other in terms of their definitions, but also with respect to the 'native regular landscape' as well as the 'stereotypical landscapes' (Kühne 2018d).

In addition to its strong emotional linkage, the 'native regular landscape' shows clear references to non-visual sensory impressions. It is "filled with first memories of regional language, sounds, smells, colours, gestures, moods and speaking things and deeply anchored in the memory" (Hüppauf 2007 p 112; see also Proshansky et al. 1983; De 
Visscher and Bouverne-De Bie 2008). Moreover, it offers a "motherly landscaped home and security" (Hard 1969, p 11). Accordingly, stories about early landscape experiences in peoples' biographies often refer to non-visual sensory stimuli (Kühne and Schönwald 2015; Kühne 2006). In contrast to the significance of non-visual stimuli in the formation of 'native regular landscapes', these are largely ignored in most 'expert special knowledge'. Raab (2001) mentions some 'quality criteria' of Western science (freedom of values, general validity and comprehensibility) as justification for this (see also Kazig 2013, 2019; Bischoff 2007; Winkler 2005). The 'expert special knowledge' represents an essential basis for the formation of 'stereotypical landscapes'. In textbooks, but also in documentaries and sometimes also in online videos, they make a significant contribution to the socialization of a positivist understanding of (geographic) space (amongst many: Ipsen 2006; Wardenga 2002; Läpple 1992). Accordingly, stereotypical notions of landscape are more intensively marked by visually perceptible elements than the 'native regular landscape'. This is likely related to the fact that the human sense of vision is usually much more dominant than the sense of hearing (Tuan 1993). However, in comparison to holders of 'expert landscape knowledge', people without a focus on visual aspects rather go along with an acoustic, olfactory, tactile and gustatory dimension (Bischoff 2007; Porteous 1985). Hence, the non-visual dimensions of landscape-even if 'unseen' - are an important part in the perception and (re-)construction of the entire landscape composite and its evaluation and meaning.

This can also be reconstructed empirically: In 2016, for instance, 447 inhabitants of the Saarland in Germany were asked in a closed questionnaire which aspects of the perceived landscape they considered as relevant for landscape representation. Approximately, two-thirds of the participants stated that sounds were part of the landscape (Kühne 2018d), which is also backed up by findings of similar earlier studies (see Rodaway 2011; Kühne 2006; Vining 1992). The interrelations between visual and non-visual landscape stimuli are particularly addressed in atmospheric landscape research (Kazig 2013, 2019).

In terms of representing non-visual stimuli of landscapes, it is a difficult challenge to grasp and 'display' the specific features helping to transport the multidimensionality and multisensory composite of the landscape. Traditional approaches of cartography often implied a 'visual translation' of this composite, as landscapes comprising other sensory dimensions were often only graphically represented (Dodt et al. 2017; Lauriault and Lindgaard 2006; Papadimitriou et al. 2009, Müller et al. 2001). Even if non-visual map elements were incorporated, they were usually linked with a $2 \mathrm{D}$ or highly generalized 3D visual representation of a landscape (see examples in chapter 2, incl. Figs. 1, 2 and 3). Ongoing developments of digital cartography and "virtual world-building', however, allow a much more (photo-)realistic and flexible (interactive) representation of the visual dimension of landscape (Edler et al. 2018b; Hruby et al. 2018; Kersten et al. 2018): these (photo-)realistic models can be linked with audiorealistic contents. This multisensory mix of spatially referenced stimuli can be merged together in easily accessible audiovisual landscape representations, such as soundscape-featured environments constructed in (immersive) Virtual Reality (VR).

The use of VR appears as an enrichment for social constructivist landscape research and, vice versa, the theoretical framing offered by social constructivist landscape theory can be an enrichment for VR. In the first scenario, empirical settings can be prepared in an idealized form to test the possibilities and limits of theory more targeted. In the second scenario, settings can be constructed theoretically, and empirical outcomes can be integrated into a more general scientific framework of landscape research (Edler et al. 2018c).

In the literature on VR-based landscapes in cartography, and GI sciences, the auditory dimension has not been in the 'focus' so far. The following technically oriented chapter shows how 3D-sound can be physically integrated into these 'walkable' multisensory 3D-landscapes (approaching a 1:1 scale).

\section{Using 3D Sound in Immersive Virtual Environments}

To add 3D sound to a 3D environment which can be accessed in immersive virtual reality, modern software solutions are required that facilitate this linkage between visual and auditory landscape representations. Unity3D is a modern (cross-platform) game engine supporting the implementation of both dimensions by quite user-friendly options. It works with common sound formats such as.mp3, wav, .aiff and .ogg (for further information on supported formats, see: https://docs.unity3d.com/Manual/AudioFiles.html), which, for instance, can be downloaded in online sound databases (e.g. https://freesound.org/) or generated with customary smartphones or mobile microphone devices.

To enrich a (visual) 3D landscape with 3D sound in Unity3D, two sound-related and invisible components must be added to a scene: an ,audio source" and an "audio listener". The audio source component plays sounds at the position of its so-called "game object", an object in the visual 3D scene that serves as an anchoring platform for the sound. In the example given in the following, the game object is a car (a virtual replica of an "Opel Manta GT/E") that 'carries' a traditional engine sound to simulate the soundscape of urban traffic (Fig. 4). The audio listener acts like a pair of digital 


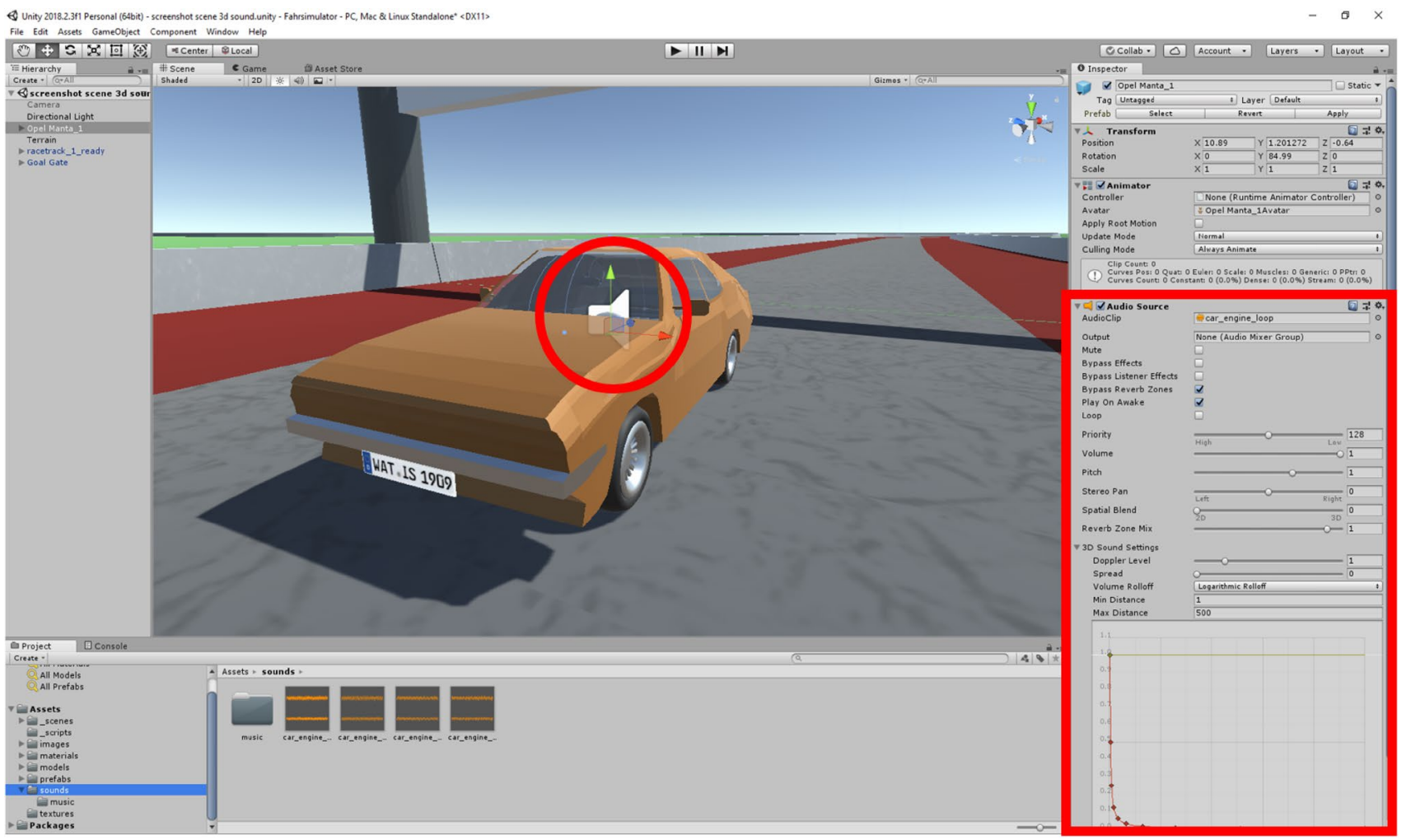

Fig. 4 An audio source component is attached to the car. This component is set to play a (repetitive) audiorealistic clip of an engine (car_engine_ loop)

ears at the position of the game object. Both components can be added to any game object in the 3D scene.

The urban soundscape of cars and traffic is an example to illustrate the different patterns of interpretation and evaluation of some parts of society. Depending on the individual (socially influenced) preference (and its intensity) for different means of transport, the evaluation of standing and driving sounds also turn out to be incorrect: A bicycle activist will probably understand the sounds of motorized individual traffic as noise. However, a friend of tuned cars will understand the sound of an Opel Manta (whose exhaust produces an acoustical intensification) as an enrichment of the urban soundscape.

In the audio source component, an audio clip is defined which should be played in the immersive audiovisual VR environment. Additionally, the audio source component contains additional sound options which can be set and changed, such as volume, minimum and maximum distance, and Doppler level (Fig. 4). Within the defined minimum distance, the sound is hearable with the defined volume level. Outside of the minimum distance, the volume will gradually decrease until it reaches zero at the defined maximum distance (behind this 'virtual 3D border', the sound is no longer hearable). The Doppler level defines whether and how intensive a Doppler effect is applied. If the value is larger than zero, the played sounds are pitched based on the movement speed and direction of their audio source, relative to the position of an audio listener. It becomes apparent that some dominant variables of Krygier's typology (1994) also occur in modern (VR-based) 3D animation software.

The audio listener component interprets audio sources around its game object. It calculates a 3D sound mix based on the position and rotation of its game object and the relative position of the surrounding audio sources. The sound mix is then transmitted to the active audio output device (e.g. headset or 5.1 sound system). If an active audio source is placed on the left side of the audio listener, the associated audio clip is played louder and minimally earlier on the left headset speaker than on the right headset speaker. This simulates natural binaural hearing. Usually, the audio source is attached to the main camera in the scene (see Fig. 5). Thus, the position from where the user sees the scene is also the position from where the 3D sound mix is calculated.

In monitor-based Unity3D applications, the main camera movement and rotation are usually manipulated by mouse and keyboard, or controller input. However, when VR or AR headsets (like HTC Vive or Microsoft Hololens) are used, the main camera position and rotation are usually set to mirror the movements of the headset. Therefore, if the audio listener component is attached to the main 


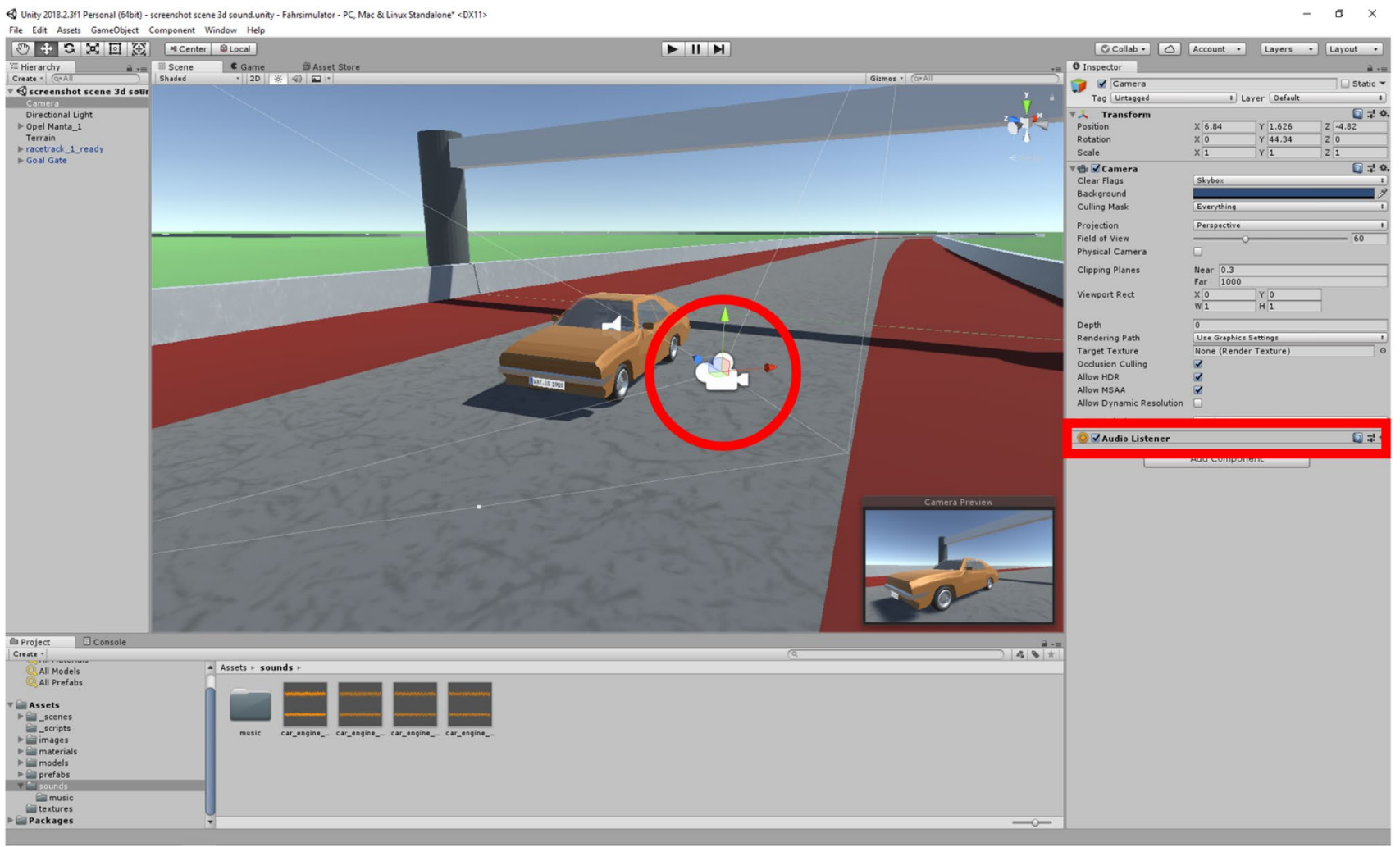

Fig. 5 An audio listener component is attached to the camera. Thus, volume and direction of played audio clips are calculated based on the relative position of their game object to the camera
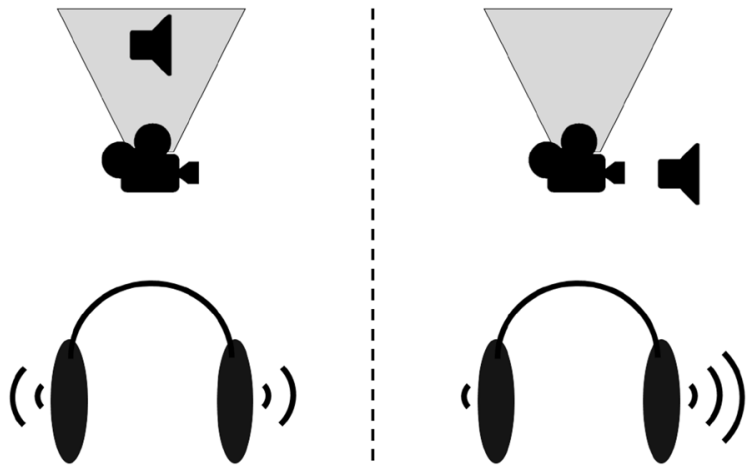

Fig. 6 The grey trapeze shows the angle of view of the camera. On the left side of the image, an audio source is directly in front of the camera (which has an attached audio listener). Therefore, the audio clip is played with the same volume in both headset speakers. On the right side of the image, the audio source is to the right of the camera. Therefore, the audio clip is played louder and minimally earlier in the right headset speaker

camera, volume of played audio clips in each of the used speakers is affected by the head movement of the user (see Fig. 6). This generates a sense of being present in the 'real physical' soundscape, where the relative position of objects can be located based on the sounds they are emitting.
The same principle of applying 3D sound can be achieved in the game engine Unreal Engine 4. Figure 7 shows 3D sound emitting from a river in a mountain area. In this example, the audiorealistic river sound is distributed sphere-like around a fixed center point of in the river stream.

\section{Summary and Outlook}

This paper has given an overview of the use of different variants of sound established in audiovisual cartography. Amongst abstract sounds and abstract sound sequences (see Krygier 1994), speech and music, audiorealistic sequences representing the "soundscape" (see Schafer 1977, also Krause 2016) of a place are a highly complex entity which can transport and represent a lot of the socially constructed meaning of landscapes.

Current 3D visualization techniques used in modern cartography (cf. Hruby et al. 2018; Kersten et al. 2018; Edler et al. 2018c) go beyond the realism transported via traditional audiovisual maps. It is possible to incorporate audiorealistic sound clips that scatter sound (clips) in 3D and that can move their (dynamic) positions in spatiotemporal animations. These cartographic techniques allow a highly realistic representation of landscapes which can 
Fig. 7 Sphere of a 3D sound object in Unreal Engine 4 representing the soundscape in a mountainous river landscape. The orange lines mark the area where the audio source can be heard

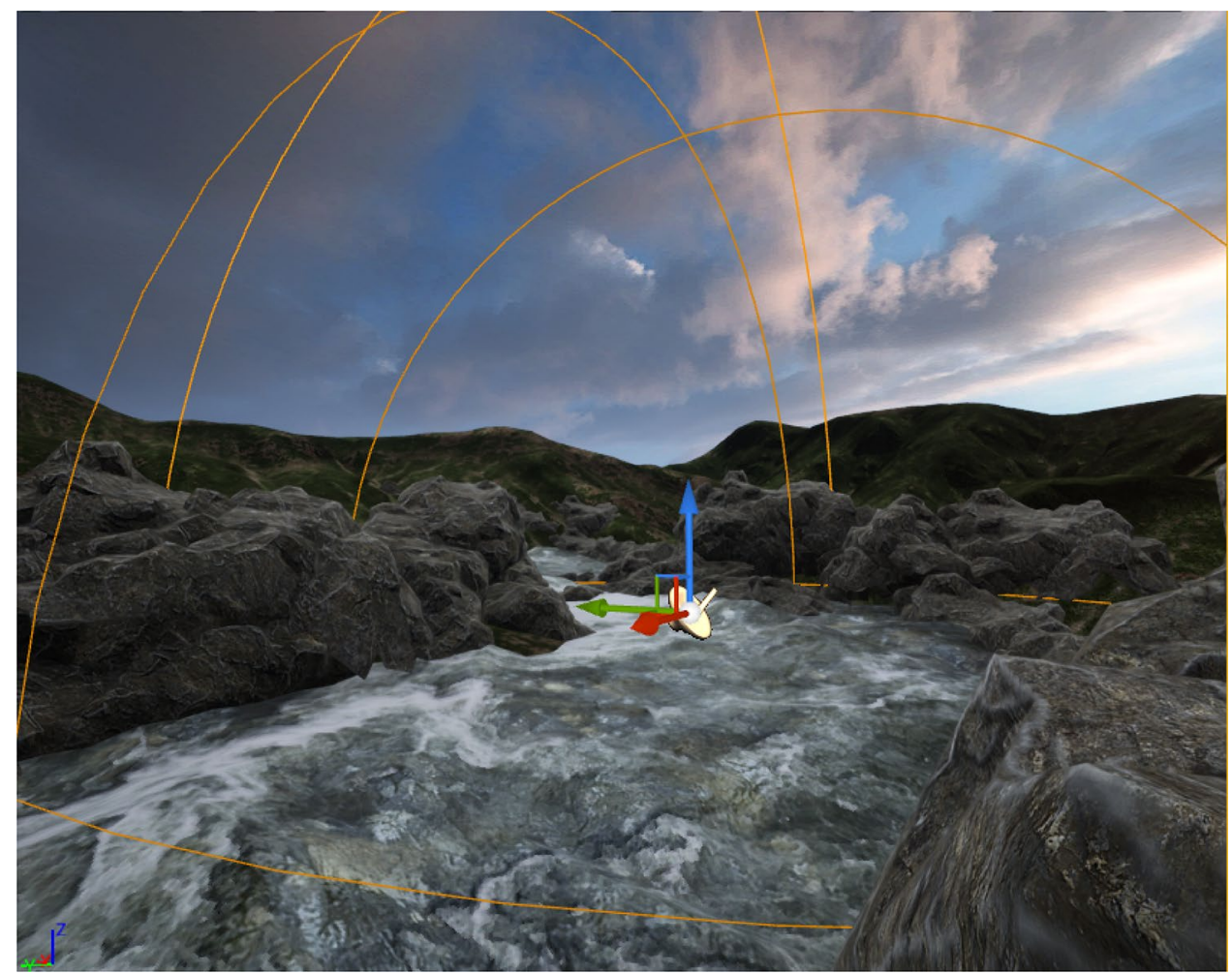

be used interactively and immersively, implying that the user takes an ego-perspective and can navigate through the audiovisual landscape simulation in real time.

Sounds have a special significance for people without expert knowledge in the construction of landscapes. In this respect, from the perspective of social constructivist landscape research, it seems very important to develop modern approaches to map and visualize this dimension of landscape. In terms of the creation of virtual landscapes, a new possibility is offered to explore the significance of the acoustic dimension in a firm way, due to the plannability of the acoustic stimuli by means of VR.

These modern options of cartographic 3D visualization, based on audiorealistic sound sequences and freely accessible game engines, bear a lot of potential for future approaches of landscape research, as these new opportunities of representing 'multisensory realism' offer a new dimension of simulated landscape experience and extend the repertoire of media that can be used in (social constructivist) landscape research. In other-and concluding-words, 3D visualization techniques and its immersive use in real time open a link between cartography and new interdisciplinary fields whose researchers had not shown a keen interest in cartography so far, due to the former lack of available innovations to create highly realistic $3 \mathrm{D}$ representations of different landscape dimensions.
Acknowledgements The authors wish to give many thanks to John B. Krygier for giving the kind permission to print Fig. 1. In addition, many thanks go to Timo Wiedenlübbert for supporting the creation of Fig. 7.

OpenAccess This article is distributed under the terms of the Creative Commons Attribution 4.0 International License (http://creativecommons.org/licenses/by/4.0/), which permits unrestricted use, distribution, and reproduction in any medium, provided you give appropriate credit to the original author(s) and the source, provide a link to the Creative Commons license, and indicate if changes were made.

\section{References}

Ahlqvist O (2011) Converging themes in cartography and computer games. Cartogr Geogr Inf Sci 38(3):278-285. https://doi. org/10.1559/15230406382278

Aiello LM, Schifanella R, Quercia D, Aletta F (2016) Chatty maps: constructing sound maps of urban areas from social media data. Royal Society Open Science: 3(150690). Online available http:// rsos.royalsocietypublishing.org/content/royopensci/3/3/15069 0.full.pdf. Accessed 11 Dec 2018

Aschenbrand E, Kühne O, Weber F (2017) Rohstoffgewinnung in Deutschland: Auseinandersetzungen und Konflikte: Eine Analyse aus sozialkonstruktivistischer Perspektive. UmweltWirtschaftsForum, online first

Axelsson Ö (2015) How to measure soundscape quality. In: Proceedings of the euronoise conference. Maastricht, The Netherlands, 31 May-3 June 2015, pp 1477-1481 
Ballatore A, Gordon D, Boone AP (2018) Sonyfying data uncertainty with sound dimensions. Cartogr Geogr Inf Sci. https://doi. org/10.1080/15230406.2018.1495103

Bearman N, Lovett A (2010) Using sound to represent positional accuracy of address locations. Cartogr J 47(4):308-314. https://doi. org/10.1179/000870410X12911302296833

Bertin J (1967) Semiologie graphique. Mouton et Gauthier- Villars, Paris

Bischoff W (2007) Nicht-visuelle Dimensionen des Städtischen: Olfaktorische Wahrnehmung in Frankfurt am Main, dargestellt an zwei Einzelstudien zum Frankfurter Westend und Ostend. BIS-Verlag, Oldenburg

Borchert A (1999) Multimedia atlas concepts. In: Cartwright W, Peterson MP, Gartner G (eds) Multimedia cartography. Springer, Berlin, pp 75-86

Brauen G (2006) Designing interactive sound maps using scalable vector graphics. Cartographica 41(1):59-71. https://doi. org/10.3138/5512-628G-2H57-H675

Brauen G (2014) Interactive audiovisual design for cartography: survey, prospects, and example. In: Lauriault T, Taylor DRF (eds) Developments in the theory and practice of cybercartography. Applications and indigenous mapping, 2nd edn. Elsevier, Amsterdam

Brauen G, Taylor DRF (2008) Linked audio representation in cybercartography: guidance from animated and interactive cartography for using sound. Revista Brasileira de Cartografia 60(3):223-242

Bruns D, Kühne O (2015) Gesellschaftliche Transformation und die Entwicklung von Landschaft - eine Betrachtung aus der Perspektive der sozialkonstruktivistischen Landschaftstheorie. In: Kühne O, Gawroński K, Hernik J (eds) Transformation und Landschaft. Die Folgen sozialer Wandlungsprozesse auf Landschaft. Springer VS, Wiesbaden, pp 9-13

Burckhardt L (2006) Warum ist Landschaft schön? Die Spaziergangswissenschaft. Martin Schmitz Verlag, Kassel

Buziek G (1999) Dynamic elements of multimedia cartography. In: Cartwright W, Peterson MP, Gartner G (eds) Multimedia cartography. Springer, Berlin, pp 231-244

Caquard S, Brauen G, Wright B, Jasen P (2008) Designing sound in cybercartography: from structured cinematic narratives to unpredictable sound/image interactions. Int J Geogr Inf Sci 22(11-12):1219-1245. https://doi.org/10.1080/1365881080 1909649

Coors V, Andrae C, Böhm K-H (2016) 3D Stadtmodelle - Konzepte und Anwendungen mit CityGML. Wichmann, Berlin

Cosgrove D (1984) Social formation and symbolic landscape. University of Wisconsin Press, London

Cosgrove D (1985) Prospect, perspective and the evolution of the landscape idea. Trans Inst Br Geogr 10(1):45-62. https://doi. org/10.2307/622249

Daniels S, Cosgrove D (1988) Introduction: iconography and landscape. In: Cosgrove D, Daniels S (eds) The iconography of landscape. Essays on the symbolic representation, design and use of past environments. CUP, Cambridge, pp 1-10

De Visscher S, Bouverne-De Bie M (2008) Recognizing urban public space as a co-educator: children's socialization in Ghent. Int J Urban Reg Res 32(3):604-616. https://doi.org/10.111 $1 /$ j.1468-2427.2008.00798.x

Dickmann F (2018) Kartographie. Westermann, Braunschweig

Dickmann F, Dunker S (2014) Visualisierung von 3D-Gebäudemodellen - Welche Ansprüche stellt die Planung an dreidimensionale Stadtansichten? Kartographische Nachrichten 64(1):10-16

Dodt J, Bestgen A-K, Edler D (2017) Ansätze der Erfassung und kartographischen Präsentation der olfaktorischen Dimension. Kartographische Nachrichten 67(5):245-256
Edler D, Dickmann F (2016) Interaktive Multimediakartographie in frühen Videospielwelten - Das Beispiel „Super Mario World“. Kartographische Nachrichten 66(2):51-58

Edler D, Dickmann F (2017) The impact of 1980s and 1990s video games on multimedia cartography. Cartographica 52(2):168-177. https://doi.org/10.3138/cart.52.2.3823

Edler D, Dodt J (2010) Eine audio-visuelle Flash-Applikation zur Fremdsprachenvermittlung. Kartographische Nachrichten 60(5):276-278

Edler D, Lammert-Siepmann N (2012) Audio-visuelle Karten für den Englischunterricht an Grundschulen. European University Press, Bochum

Edler D, Lammert-Siepmann N, Dodt J (2012) Die akustische Dimension in der Kartographie - eine Übersicht. Kartographische Nachrichten 62(4):185-195

Edler D, Jebbink K, Dickmann F (2015) Einsatz audio-visueller Karten in der Schule - Eine Unterrichtsidee zum Strukturwandel im Ruhrgebiet. Kartographische Nachrichten 65(5):259-265

Edler D, Kühne O, Jenal C, Vetter M, Dickmann F (2018a) Potenziale der Raumvisualisierung in Virtual Reality (VR) für die sozialkonstruktivistische Landschaftsforschung. Kartographische Nachrichten 68(5):245-254

Edler D, Keil J, Dickmann F (2018b) Varianten interaktiver Karten in Video- und Computerspielen - eine Übersicht. Kartographische Nachrichten 68(2):57-65

Edler D, Husar A, Keil J, Vetter M, Dickmann F (2018c) Virtual Reality (VR) and open source software: a workflow for constructing an interactive cartographic VR environment to explore urban landscapes. Kartographische Nachrichten 68(1):3-11

Francis K (1999) Wula Na Lnuwe'kati: a digital multimedia atlas. In: Cartwright W, Peterson MP, Gartner G (eds) Multimedia cartography. Springer, Berlin, pp 141-148

Gailing L (2013) Die Landschaften der Energiewende - Themen und Konsequenzen für die sozialwissenschaftliche Landschaftsforschung. In: Gailing L, Leibenath M (eds) Neue Energielandschaften - Neue Perspektiven der Landschaftsforschung. Springer VS, Wiesbaden, pp 207-215

Garfield S (2012) On the map. Why the world looks the way it does. Profile Books, London

Greider T, Garkovich L (1994) Landscapes: the social construction of nature and the environment. Rural Sociol 59(1):1-24. https://doi. org/10.1111/j.1549-0831.1994.tb00519.x

Grimshaw M (2014) Sound. In: Wolf MJP, Perron B (eds) The Routledge companion to video game studies. Routledge, New York, pp 117-124

Günther-Diringer D (2016) Historisches 3D-Stadtmodell von Karlsruhe. Kartographische Nachrichten 66(2):66-71

Hard G (1969) Das Wort Landschaft und sein semantischer Hof: Zur Methode und Ergebnis eines linguistischen Tests. Wirkendes Wort 19:3-14

Harrower M (2004) A look at the history and future of animated maps. Cartographica 39(3):33-42. https://doi. org/10.3138/7MN7-5132-1MW6-4V62

Helmuth M, Davis T (2004) Rock music: a granular and stochastic synthesis based on the Matanuska glacier. In: Proceedings of ICMC 2004: the 30th annual international computer music conference. Miami, USA. http://marahelmuth.com/research/RockM usicFinalFinal.pdf. Accessed 11 Dec 2018

Hruby F, Ressl R, de la Valle BG (2018) Geovisualization with immersive virtual environments in theory and practice. Int J Digit Earth 25:8. https://doi.org/10.1080/17538947.2018.1501106

Hüppauf B (2007) Heimat - die Wiederkehr eines verpönten Wortes: Ein Populärmythos im Zeitalter der Globalisierung. In: Gebhard G, Geisler O, Schröter S (eds) Heimat. Konturen und Konjunkturen eines umstrittenen Konzepts. Transcript Verlag, Bielefeld, pp 109-140 
Ipsen D (2006) Ort und Landschaft. VS Verlag für Sozialwissenschaften, Wiesbaden

Kazig R (2013) Landschaft mit allen Sinnen - Zum Wert des Atmosphärenbegriffs für die Landschaftsforschung. In: Bruns D, Kühne $\mathrm{O}$ (eds) Landschaften: theorie, Praxis und internationale Bezüge. Oceano Verlag, Schwerin, pp 221-232

Kazig R (2019) Für ein alltagsästhetisches Verständnis von Heimat. In: Hülz M, Kühne O, Weber F (eds) Heimat. Ein vielfältiges Konstrukt. Springer VS, Wiesbaden. (Accepted, in print)

Kersten TP, Deggim S, Tschirschwitz F, Lindstaedt M, Hinrichsen N (2018) Segeberg 1600 - Eine Stadtrekonstruktion in Virtual Reality. Kartographische Nachrichten 68(4):183-191

Kornfeld A-L (2008) Die kartographische Visualisierung des akustischen Raums. Kartographische Nachrichten 58(6):294-301

Krause B (2016) Wild soundscapes. Discovering the voice of the natural world. Yale University Press, New Haven

Krygier JB (1991) An elemental approach to animation and sound in information graphics. Along with an apologia for doing it. [Seminar Paper, for Mark Detweiler, in Psychology 597a]. https ://makingmaps.files.wordpress.com/2008/03/sound_paper_detwe iler.pdf. Accessed 11 Dec 2018

Krygier JB (1993) Mapping with sound. Online available https://makin gmaps.net/author/environmentalgeography/page/7/. Accessed 11 Dec 2018

Krygier JB (1994) Sound and geographic visualization. In: MacEachren AM, Taylor DRF (eds) Visualization in modern cartography. Elsevier, Oxford, pp 149-166

Kühne O (2006) Landschaft in der Postmoderne: Das Beispiel des Saarlandes. DUV, Wiesbaden

Kühne O (2008a) Die Sozialisation von Landschaft - sozialkonstruktivistische Überlegungen, empirische Befunde und Konsequenzen für den Umgang mit dem Thema Landschaft in Geographie und räumlicher Planung. Geogr Z 96(4):189-206

Kühne O (2008b) Distinktion - Macht - Landschaft: Zur sozialen Definition von Landschaft. VS Verlag für Sozialwissenschaften, Wiesbaden

Kühne O (2009) Heimat und Landschaft - Zusammenhänge und Zuschreibungen zwischen Macht und Mindermacht. Überlegungen auf sozialkonstruktivistischer Grundlage. Stadt + Grün 9:17-22

Kühne O (2018a) Landschaftstheorie und Landschaftspraxis: Eine Einführung aus sozialkonstruktivistischer Perspektive. Springer VS, Wiesbaden

Kühne O (2018b) Die Moralisierung von Landschaft - Überlegungen zu einer problematischen Kommunikation aus Sicht der Luhmannschen Systemtheorie. In: Hennecke S, Kegler H, Klaczynski K, Münderlein D (eds) Diedrich Bruns wird gelehrt haben. Eine Festschrift. Kassel University Press, Kassel, pp 115-121

Kühne O (2018c) Landschaft und Wandel: Zur Veränderlichkeit von Wahrnehmungen. Springer VS, Wiesbaden

Kühne O (2018d) Landscape and power in geographical space as a social-aesthetic construct. Springer International Publishing, Dordrecht

Kühne O (2018e) Der doppelte Landschaftswandel: physische Räume, soziale Deutungen, Bewertungen. Nachrichten der ARL 48(1):14-17

Kühne O, Schönwald A (2015) San Diego: Eigenlogiken, Widersprüche und Hybriditäten in und von, America's finest city'. Springer VS, Wiesbaden

Laakso M, Sarjakoski LT (2010) Sonic maps for hiking—use of sound in enhancing the map use experience. Cartogr J 47(4):300-307. https://doi.org/10.1179/000870410X12911298276237

Lammert-Siepmann N, Edler D, Redecker AP, Jürgens C (2011) Designing teaching units via WebGIS: remotely sensed imagery in the language classroom. EARSeL eProc 10(2):149-158
Lammert-Siepmann N, Edler D, Dickmann F (2014) Die Effekte audiovisueller Informationsvermittlung in Topographischen Karten auf die Behaltensleistung - Das Beispiel geographische Namen. Kartographische Nachrichten 64(6):308-316

Lammert-Siepmann N, Bestgen A-K, Edler D, Kuchinke L, Dickmann F (2017) Audiovisual communication of object-names improves the spatial accuracy of recalled object-locations in topographic maps. PLoS One 12(10):e0186065. https://doi.org/10.1371/journ al.pone. 0186065

Läpple D (1992) Essay über den Raum: Für ein gesellschaftswissenschaftliches Raumkonzept. In: Häußermann H, Ipsen D, KrämerBadoni R, Läpple D, Rodenstein M, Siebel W (eds) Stadt und Raum. Soziologische Analysen. Centaurus, Pfaffenweiler, pp $157-207$

Lauriault TP, Lindgaard G (2006) Scented cybercartography: exploring possibilities. Cartographica 41(1):73-91. https://doi.org/10.3138/ W432-713U-3621-04N3

Linke S (2017) Ästhetik, Werte und Landschaft - eine Betrachtung zwischen philosophischen Grundlagen und aktueller Praxis der Landschaftsforschung. In: Kühne O, Megerle H, Weber F (eds) Landschaftsästhetik und Landschaftswandel. Springer VS, Wiesbaden, pp 23-40

MacEachren AM (2004) How maps work. Representation, visualization, and design. Guilford Press, New York

Morrison JL, Ramirez JR (2001) Integrating audio and user-controlled text to query digital databases and to present geographic names on digital maps and images. In: Proceedings of the 20th international cartographic conference, Beijing, China. http://icaci.org/ files/documents/ICC_proceedings/ICC2001/icc2001/file/f1200 5.doc. Accessed 11 Dec 2018

Müller J-C (1997) GIS, Multimedia und die Zukunft der Kartographie. Kartographische Nachrichten 47(2):41-51

Müller J-C, Laurini R (1997) La cartographie de l'an 2000. Revue Internationale de Géomatique 7(1):87-106

Müller J-C, Scharlach H, Jäger M (2001) Der Weg zu einer akustischen Kartographie. Kartographische Nachrichten 51(1):26-40

Papadimitriou KD, Mazaris AD, Kallimanis AS, Pantis JD (2009) Cartographic representation of the sonic environment. Cartogr J 46(2):126-135. https://doi.org/10.1179/000870409X459842

Peterson MP (1999) Active legends for interactive cartographic animation. Int J Geogr Inf Sci 13(4):375-383

Porteous DJ (1985) Smellscape. Prog Hum Geogr 9(3):356-378

Proshansky HM, Fabian AK, Kaminoff R (1983) Place-identity: physical world socialization of the self. J Environ Psychol 3(1):57-83. https://doi.org/10.1016/S0272-4944(83)80021-8

Pulsifer PL, Caquard S, Taylor DRF (2007) Toward a new generation of community atlases - The Cybercartographic Atlas of Antarctica. In: Cartwright W, Peterson MP, Gartner G (eds) Multimedia cartography, 2nd edn. Springer, Berlin, pp 195-216

Raab J (2001) Soziologie des Geruchs: Über die soziale Konstruktion olfaktorischer Wahrnehmung. UVK Verlagsgesellschaft, Konstanz

Reagan I, Baldwin CL (2006) Facilitating route memory with auditory route guidance systems. J Environ Psychol 26(2):146-155. https ://doi.org/10.1016/j.jenvp.2006.06.002

Rodaway P (2011) Sensuous geographies: body, sense, and place. Routledge, London

Schafer RM (1977) The soundscape. Our sonic environment and the tuning of the world. Destiny Books, Rochester

Scharlach H (2002) Lärmkarten. Kartographische Grundlagen und audiovisuelle Realisierung. $\mathrm{PhD}$ thesis, Ruhr University Bochum. http://www-brs.ub.ruhr-uni-bochum.de/netahtml/HSS/Diss/Schar lachHolger/diss.pdf. Accessed 11 Dec 2018

Schiewe J (2015) Physiological and cognitive aspects of sound maps for representing quantitative data and changes in data. In: Brus J, 
Vondrakova A, Vozenilek V (eds) Modern trends in cartography. Selected papers of CARTOCON 2014, Springer, Heidelberg, pp 315-324

Schiewe J, Weninger B (2012) Akustische Kodierung quantitativer Information in Karten - Ergebnisse einer Studie zum Vergleich mir klassischen Darstellungsformen. Kartographische Nachrichten 62(3):126-135

Schito J (2011) Effizienzanalyse der akustischen Wahrnehmung einer Parameter Mapping Sonification eines digitalen Höhenmodells durch interaktive Datenexploration. Master Thesis, University of Zurich

Schito J, Fabrikant SI (2018) Exploring maps by sounds: using parameter mapping sonification to make digital elevation models audible. Int J Geogr Inf Sci. https://doi.org/10.1080/13658 816.2017.1420192

Schütz A (1960) [1932] Der sinnhafte Aufbau der sozialen Welt: Eine Einleitung in die Verstehende Soziologie. Julius Springer, Wien

Schütz A (1971) Gesammelte Aufsätze 3: Studien zur phänomenologischen Philosophie. Martinus Nijhoff, Den Haag

Siekierska EM, Armenakis C (2007) Territorial evolution of Canadaan interactive multimedia cartographic application. In: Cartwright W, Peterson MP, Gartner G (eds) Multimedia cartography, 2nd edn. Springer, Berlin, pp 117-127

Sobue S-I, Araki H, Tazawa S, Noda H, Kamiya I, Yamamoto A, Fujita T, Higashiizumi I, Okumura H (2010) An application of lunar GIS with visualized and auditory Japan's lunar explorer "KAGUYA" data. In: Elleithy K (ed) Advanced techniques in computing sciences and software engineering. Springer, Dordrecht, pp 159-163

Sonnenschein D (2001) Sound design. The expressive power of music, voice, and sound effects in cinema. Michael Wiese Productions, Studio City

Stotten R (2013) Kulturlandschaft gemeinsam verstehen - Praktische Beispiele der Landschaftssozialisation aus dem Schweizer

\section{Affiliations}

\section{Dennis Edler ${ }^{1}$. Olaf Kühne ${ }^{2}$. Julian Keil ${ }^{1}$. Frank Dickmann ${ }^{1}$}

Dennis Edler

dennis.edler@rub.de

Olaf Kühne

olaf.kuehne@uni-tuebingen.de

Julian Keil

julian.keil@ rub.de

Frank Dickmann

frank.dickmann@rub.de
Alpenraum. Geogr Helv 68(2):117-127. https://doi.org/10.5194/ gh-68-117-2013

Théberge P (2005) Sound maps: music and sound in cybercartography. In: Taylor DRF (ed) Cybercartography: theory and practice. Elsevier, Amsterdam, pp 380-410

Thirion S (2007) Cascade on wheels: traffic mixer. http://www.trsp.net/ cow/. Accessed 11 Dec 2018

Tuan Y-F (1993) Voices, sounds and heavenly music. In: Tuan Y-F (ed) Passing strange and wonderful aesthetics, nature, and culture. Island Press, Washington, DC, pp 70-95

Vining J (1992) Environmental emotions and decisions: a comparison of the responses and expectations of forest managers, an environmental group, and the public. Environ Behav 24(1):3-34. https:// doi.org/10.1177/0013916592241001

Wardenga U (2002) Alte und neue Raumkonzepte für den Geographieunterricht. Geographie heute 23(200):8-11

Weber F (2018) Konflikte um die Energiewende: Vom Diskurs zur Praxis. Springer VS, Wiesbaden

Weber F, Kühne O, Jenal C, Aschenbrand E, Artuković A (2018) Sand im Getriebe: Aushandlungsprozesse um die Gewinnung mineralischer Rohstoffe aus konflikttheoretischer Perspektive nach Ralf Dahrendorf. Springer VS, Wiesbaden

Winkler J (2005) Raumzeitphänomen Klanglandschaften. In: Denzer V, Hasse J, Kleefeld K-D, Recker U (eds) Kulturlandschaft. Wahrnehmung - Inventarisation - regionale Beispiele. Habelt, Bonn, pp 77-88

Wissmann T (2014) Geographies of urban sound. Routledge, Abingdon Wojtkiewicz W, Heiland S (2012) Landschaftsverständnisse in der Landschaftsplanung: Eine semantische Analyse der Verwendung des Wortes „Landschaft“in kommunalen Landschaftsplänen. Raumforsch Raumordn 70(2):133-145. https://doi.org/10.1007/ s13147-011-0138-7
1 Geomatics/Cartography Group, Geography Department, Ruhr University Bochum, Bochum, Germany

2 Urban and Regional Development, Eberhard Karls University Tübingen, Tübingen, Germany 